\title{
The Environmental Assessment of Biomass Waste Conversion to Sustainable Energy in the Agricultural Biogas Plant
}

\author{
Magdalena Muradin
}

\begin{abstract}
Operating an agricultural biogas plants offers the potential of stable, clean, renewable and diversified energy source. It is also a good opportunity to reduce the amount of organic waste. The objective of this study is to evaluate the main environmental hot spots of operating agricultural biogas plants using LCA methodology. This article presents the environmental impact assessment of two agricultural biogas plants with different type of feedstock provision. The environmental life cycle assessment was carried out from "cradle to gate" using the SimaPro software and the ILCD 2011 Midpoint+ methodology. The boundaries of the system included cultivation of maize, delivery of feedstock to the plant, energy production, storage and transport of digestate. The results show that transport of liquid manure induces the highest environmental impact.
\end{abstract}

\section{Introduction}

In 2019, the European Parliament assigned the resolution on the climate and environment emergency. Based on that, it is an urgent need to implement and develop many new technologies especially in energy sector, to prevent the further intensification of the crisis and reduce the global temperature growth.

It was expected that carbon dioxide produced by human activity would be absorbed by the oceans. Meanwhile, by warming the atmosphere, $\mathrm{CO}_{2}$ is additionally released from the oceans and melting ice, so that its concentration may increase exponentially and cause more and more negative climatic phenomena. Food production and consumption account for as much as $35 \%$ of all greenhouse gases in the atmosphere, of which agriculture alone accounts for $10 \%$.

Developed countries are struggling with ever-increasing amounts of waste, including the agri-food industry waste, due to overproduction and consumption of food. The issue of the generation of biodegradable waste is often marginalized, while animal production and the generated livestock manure contribute to $30 \%$ of

M. Muradin ( $\triangle)$

Poznan University of Economics and Business, Poznan, Poland

e-mail: magdalena.muradin@ue.poznan.pl 
the total emission of anthropogenic methane to the atmosphere. The global warming potential for methane is from 23 , which means that the same amount of methane in the atmosphere as $\mathrm{CO}_{2}$ will have a 23 more significant impact on climate warming. Technologies based on anaerobic digestion are very useful in reducing the amount of waste from agri-food industry and at the same time enable controlled methane capture and energy production in cogeneration systems.

Manure is a livestock residue that has little commercial value [1]. The slurry digestate which is a result of the anaerobic fermentation can be used as more bioavailable fertilizer form [2] and helps to reduce the number of pathogens entering the soil with direct application. Furthermore, storing animal manure in the open air results in methane and carbon dioxide emissions through the process of selfremediation [3]. Anaerobic digestion of animal manure reduces the environmental impacts caused by carbon dioxide, methane and nitrous oxide emissions from storage and reduces waste and odours [4]. For example, in Finland case, anaerobic fermentation on cattle farms contributes to the reduction at approximately $9 \%$ of the national agricultural GHG emission reduction goal during the 2005-2020 period [5].

However, animal manure has low biogas yield $\left(9-36 \mathrm{~m}^{3} / \mathrm{Mg}\right.$ ) compared with different feedstock especially maize silage. In this case, the co-digestion of different biodegradable substrates is often used at farms. The most effective in producing biogas is digesting liquid manure with maize silage, what is however economically unfavourable, and what even worse, maize cultivation for the energy production purpose stays against cultivation for feeding. The solution could be co-digestion with different waste from agri-food production. Such products have often relatively higher methane yield than manure, e.g. potato pulp or fruit pomace. Very favourable to use as a feedstock is also distillery waste. The methane yield for that waste is lower and similar to liquid manure but to manage with this waste is also very problematic and biogas plant can be a solution.

Anaerobic digestion seems to be a very efficient way to close the material and nutrient loop according to EU circular economy paradigm. The field application of digestate is also a part of nutrients' circularity. Digestated materials have advantages for their use as soil amendments which are microbial stability, hygiene and high amount of $\mathrm{N}$ present as ammonium. It improves also the total organic $\mathrm{C}$ concentration in soil $[6,7]$.

Biogas is a promising substitute for natural gas of fossil origin [8]. Published articles about environmental impact of biogas production analysed heat and energy production [9], biomethane purification [10] and domestic use [11]. Reviews also describe biogas LCA from manure in a global perspective, technological studies of biogas production and specific studies for specific countries or region. Studies also concern a transport of feedstock and indicate that it can play an important role in the environmental performance of biogas production [12]. The maximum transportation distance should not extend $10 \mathrm{~km}$ to make biogas environmentally viable for small-scale plants [9, 13], and for large-scale plants, it should be within $64 \mathrm{~km}$ [14]. However, mostly studies focus on electricity generation from biogas than on the possibility of biomass waste treatment. 
The aim of this paper is to present the results of selected two biogas plants, which mostly differ with the type of feedstock, the way it is transported and the transportation distance, in order to highlight the most critical factors (hot spots) from the environmental point of view of operating those installations whose main purpose is the waste treatment.

\section{Materials and Methods}

The life cycle assessment (LCA) methodology was chosen for this study based on ISO 14040 and ISO 14044 as the most comprehensive evaluation of environmental impact. LCA analysis includes four steps: goal and scope definition, life cycle inventory analysis, life cycle impact assessment and interpretation of results [15, 16]. In this work, the ILCD 2011 Midpoint+ v.1.10 method was considered. The ILCD was developed by the Institute for Environment and Sustainability in the European Commission Joint Research Centre (JRC), in cooperation with the Environment DG which is widely used in Europe. In this method, 16 very detailed impact assessment categories are distinguished [17]. The inventory data for this study were taken directly from tested agricultural biogas plants located in Poland and from the ecoinvent database v. 3.3 and processed using the SimaPro calculation program.

Selected biogas plants were assessed in details from gate-to-gate perspective. Input data were collected for separate unit processes implemented under the modern mesophilic fermentation technology: maize cultivation, feedstock delivery, energy production and digestate storage and transport. All results were analysed relative to the reference unit, which is named as a functional unit (FU) and defined as "a delivery of $1000 \mathrm{Mg}$ of feedstock designed to biogas conversion". The values of the ecoindicator were presented in impact categories, expressing the value of impact at environmental ecopoints (marked with the Pt symbol).

The allocation cut-off by classification model was used in this study, and the primary production of input of raw materials and pig slurry was allocated to the primary user/producer. It was also considered that the main product is electricity with $100 \%$ allocation, but the main purpose of those plants is the biomass waste management. Only the maize cultivation was taken into consideration as a dedicated tillage.

Two agricultural biogas plants $\mathrm{A}$ and $\mathrm{B}$ were taken into consideration with installed power 1.0 MW and $0.526 \mathrm{MW}$, respectively. In both cases, slurry digestate is not separated and used as a natural fertilizer on arable fields. The most important parameters of the tested plants are collected in Table 1. The construction and demolition of the biogas plant as well as the production of biomass waste feedstock and digestate application on fields were excluded from the scope of the study. The environmental impacts of the electricity production from biogas based on anaerobic co-digestion of pig slurry, silage maize and different feedstock from agri-food industry were determined (Table 2). 
Table 1 The most important parameters of the tested biogas plants

\begin{tabular}{l|l|l}
\hline Parameter & Biogas plant A & Biogas plant B \\
\hline The amount of biogas [m/3ear] & $4,169,760$ & $1,725,155$ \\
\hline The amount of electricity produced [MWh/ year] & 786.1 & 300.7 \\
\hline The amount of heat produced [MWh/ year] & 776.9 & 319.3 \\
\hline The amount of heat used [MWh/ year] & 147.0 & 222.1 \\
\hline The amount of digestate [m/3ear] & 35,515 & 19,744 \\
\hline Total efficiency [\%] & 51 & 69 \\
\hline
\end{tabular}

Table 2 The feedstock input in relation to annual operations

\begin{tabular}{l|l|l|l|l}
\hline $\begin{array}{l}\text { Biogas } \\
\text { plant }\end{array}$ & $\begin{array}{l}\text { Type of } \\
\text { feedstock }\end{array}$ & $\begin{array}{l}\text { The amount of feedstock } \\
{[\mathrm{Mg} / \mathrm{year}]}\end{array}$ & $\begin{array}{l}\text { Biogas yield } \\
{\left[\mathrm{m}^{3} / \mathrm{Mg}\right]}\end{array}$ & $\begin{array}{l}\text { Maximum transport } \\
\text { distance }[\mathrm{km}]\end{array}$ \\
\hline \multirow{2}{*}{$\mathrm{A}$} & Pig slurry & $14,824.0$ & 232.0 & 5.0 \\
\cline { 2 - 5 } & Maize silage & $21,693.0$ & 36.0 & 1.0 \\
\hline \multirow{3}{*}{$\mathrm{B}$} & Maize silage & $2,025.0$ & 230.0 & 45.0 \\
\cline { 2 - 5 } & $\begin{array}{l}\text { Distillery } \\
\text { residues }\end{array}$ & $11,489.7$ & 31.0 & Gravity pipeline \\
\cline { 2 - 5 } & Carrot pomace & $1,595.9$ & 76.0 & 11.3 \\
\cline { 2 - 5 } & Potato pomace & $5,919.6$ & 94.0 & 22.5 \\
\cline { 2 - 5 } & Pig slurry & 590.0 & 9.0 & 3.8 \\
\cline { 2 - 5 } & $\begin{array}{l}\text { Protein } \\
\text { sediments }\end{array}$ & 402.6 & 700.0 & 172.5 \\
\hline
\end{tabular}

Liquid animal manure was transported by a farm tractor with a barrel. Maize harvested from the fields was transported to a biogas plant using heavy wheeled transport. The remaining raw materials from the agri-food industry were transported with a trailer or with different types of lorries. Only distillery residues in biogas plant B were delivered by a gravity pipeline.

\section{Results and Discussion}

The results were estimated by using the ILCD 2011+ method and the 16 midpoint categories. The results were described on two different levels of LCA methodology: characterization and weighting for four-unit processes - maize cultivation, feedstock delivery, energy production and digestate storage and transport. The feedstock delivery includes transport of agri-food residues, maize ensilaging on-site and delivery to the digester. In analysed biogas plants, we can distinguish six types of transport: (1) road transport of pig slurry to the plant, (2) road transport of raw materials to the plant, (3) pipeline transport to the plant, (4) internal transport on-site, (5) maize transport from the field and (6) digestate transport for final use as fertilizer.

The cumulative environmental impact of biogas plant $\mathrm{B}(1.48 \mathrm{kPt})$ is significantly lower than that of biogas plant A $(42.66 \mathrm{kPt})$. The liquid feedstock with low 
organic mass content and biogas yield in plant $\mathrm{B}$ are provided by gravity pipeline. In an installation A, a feedstock is delivered by a tractor with a barrel (Table 3). The highest environmental burdens of biogas plant A stem from the delivery of a feedstock, whereas of plant $\mathrm{B}$, it is related to the storage and transport of the digestate.

The highest value of eco-indicator for plant B concerns the digestate storage and transport. In this case, the transport of liquid digestate takes place using a tractor with a barrel. The storage of the digestate itself does not involve any energy consumption or emissions to the atmosphere. The digestate is stored in a sealed container, so transport in this process is the main contributor. Moreover, the fields for the application of the digestate are located in the vicinity of biogas plant B and the distance is $0.9616 \mathrm{~km}$ maximum. The transportation distance of a digestate to biogas plant $\mathrm{A}$ is almost twice longer $(1,606 \mathrm{~km})$, which can significantly affect the higher environmental impact. The area required for the spreading of the digestate and the maximum transportation distance were calculated as follows [18].

Biogas plant A exhibits a significant impact on almost all categories; however, the contribution of all categories for both biogas plants is almost equal (Table 4).

Only for the water resource depletion category for both biogas plants, the value is below zero. It means that in this category, the environmental impact can be positive. The lower is the value, the more positive is the impact. The reason for obtaining such results for this impact category is the temporary storage of the liquid digestate. It may provide a reservoir of water for field irrigation just next to the fertilization purpose.

Based on the results, three leading groups of factors with the highest environmental impact were separated: transport, electricity consumption and others. The factors were classified in terms of the value of environmental burdens and significance for the impact on climate change. In both biogas plants, transport is the main contributor and represents $99.9 \%$ and $98.1 \%$ of the total cumulative impact value, respectively (Fig. 1). Even electricity consumption, which in both cases comes from the grid, represents a negligible part of the total impact, $0.03 \%$ and $1.56 \%$, respectively (Fig. 1).

Comparing all different types of transport as it was mentioned earlier in this article, for biogas plant $\mathrm{A}$, the highest environmental impact is related to the transport of pig slurry (91\%), while for biogas plant B, the impact mainly stems from the transport of the digestate (87\%) (Fig. 2). The transport of raw materials to biogas plant B is characterized by a relatively low environmental impact, even though the distance from the production site to the biogas plant is up to $100 \mathrm{~km}$. Raw materials from agri-food industry such as fruits and vegetable pomace have a higher organic mass content and a higher biogas yield per unit weight (Table 2). Then the

Table 3 The cumulative eco-indicator values for individual stages of operation

\begin{tabular}{l|l|l|l|l}
\hline $\begin{array}{l}\text { Biogas } \\
\text { plant }\end{array}$ & $\begin{array}{l}\text { Maize cultivation } \\
{[\mathrm{kPt}]}\end{array}$ & $\begin{array}{l}\text { Feedstock } \\
\text { delivery }[\mathrm{kPt}]\end{array}$ & $\begin{array}{l}\text { Energy production } \\
{[\mathrm{kPt}]}\end{array}$ & $\begin{array}{l}\text { Digestate storage and } \\
\text { transport }[\mathrm{kPt}]\end{array}$ \\
\hline $\mathrm{A}$ & 0.58 & 38.68 & 0.01 & 3.39 \\
\hline $\mathrm{B}$ & 0.01 & 0.18 & 0.02 & 1.27 \\
\hline
\end{tabular}


Table 4 LCIA results of each biogas plant on the characterization level

\begin{tabular}{l|l|l|l}
\hline Impact category & Unit & Plant A & Plant B \\
\hline Climate change & $\mathrm{kg} \mathrm{CO}_{2}$ eq & $1.93 \mathrm{E}+07$ & $957 \mathrm{E}+05$ \\
\hline Ozone depletion & $\mathrm{kg} \mathrm{CFC}-11$ eq & $2.30 \mathrm{E}+00$ & $134 \mathrm{E}-01$ \\
\hline Human toxicity, non-cancer effects & $\mathrm{CTUh}$ & $5.82 \mathrm{E}+01$ & $1.85 \mathrm{E}+00$ \\
\hline Human toxicity, cancer effects & $\mathrm{CTUh}$ & $2.12 \mathrm{E}+00$ & $7.84 \mathrm{E}-02$ \\
\hline Particulate matter & $\mathrm{kg} \mathrm{PM} 2.5 \mathrm{eq}$ & $1.82 \mathrm{E}+04$ & $7.31 \mathrm{E}+02$ \\
\hline Ionizing radiation HH & $\mathrm{kBq} \mathrm{U} 235 \mathrm{eq}$ & $1.26 \mathrm{E}+06$ & $6.50 \mathrm{E}+04$ \\
\hline Ionizing radiation E (interim) & $\mathrm{CTUe}$ & $6.65 \mathrm{E}+00$ & $3.67 \mathrm{E}-01$ \\
\hline Photochemical ozone formation & $\mathrm{kg} \mathrm{NMVOC} \mathrm{eq}$ & $1.59 \mathrm{E}+05$ & $6.70 \mathrm{E}+03$ \\
\hline Acidification & molc H+ eq & $1.61 \mathrm{E}+05$ & $6.86 \mathrm{E}+03$ \\
\hline Terrestrial eutrophication & $\mathrm{molc} \mathrm{N}$ eq & $5.56 \mathrm{E}+05$ & $2.36 \mathrm{E}+04$ \\
\hline Freshwater eutrophication & $\mathrm{kg} \mathrm{P} \mathrm{eq}$ & $5.93 \mathrm{E}+03$ & $2.47 \mathrm{E}+02$ \\
\hline Marine eutrophication & $\mathrm{kg} \mathrm{N} \mathrm{eq}$ & $5.11 \mathrm{E}+04$ & $2.17 \mathrm{E}+03$ \\
\hline Freshwater ecotoxicity & $\mathrm{CTUe}$ & $3.02 \mathrm{E}+08$ & $1.14 \mathrm{E}+07$ \\
\hline Land use & $\mathrm{kg} \mathrm{C} \mathrm{deficit}$ & $1.35 \mathrm{E}+08$ & $5.37 \mathrm{E}+06$ \\
\hline Water resource depletion & $\mathrm{m}^{3}$ water eq & $-1.94 \mathrm{E}+06$ & $-5.85 \mathrm{E}+04$ \\
\hline Mineral, fossil and ren resource depletion & $\mathrm{kg} \mathrm{Sb}$ eq & $3.27 \mathrm{E}+03$ & $1.27 \mathrm{E}+02$
\end{tabular}

B

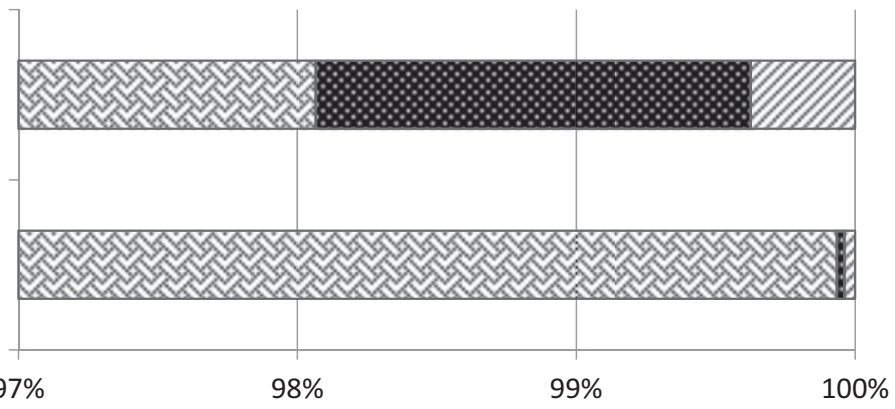

$\otimes$ Transport

Fig. 1 The contribution of main critical factors in total environmental impact

transportation can be significantly extended obtaining the same results compared with the distance for pig slurry. In plant B, the distillery residues were transported by gravity pipeline what leads to negligible environmental impact at the exploitation stage. The impact can be visible at the construction or demolition stage when the input of metal used for pipelines is taken into account. However, in this study, these two stages were omitted. 


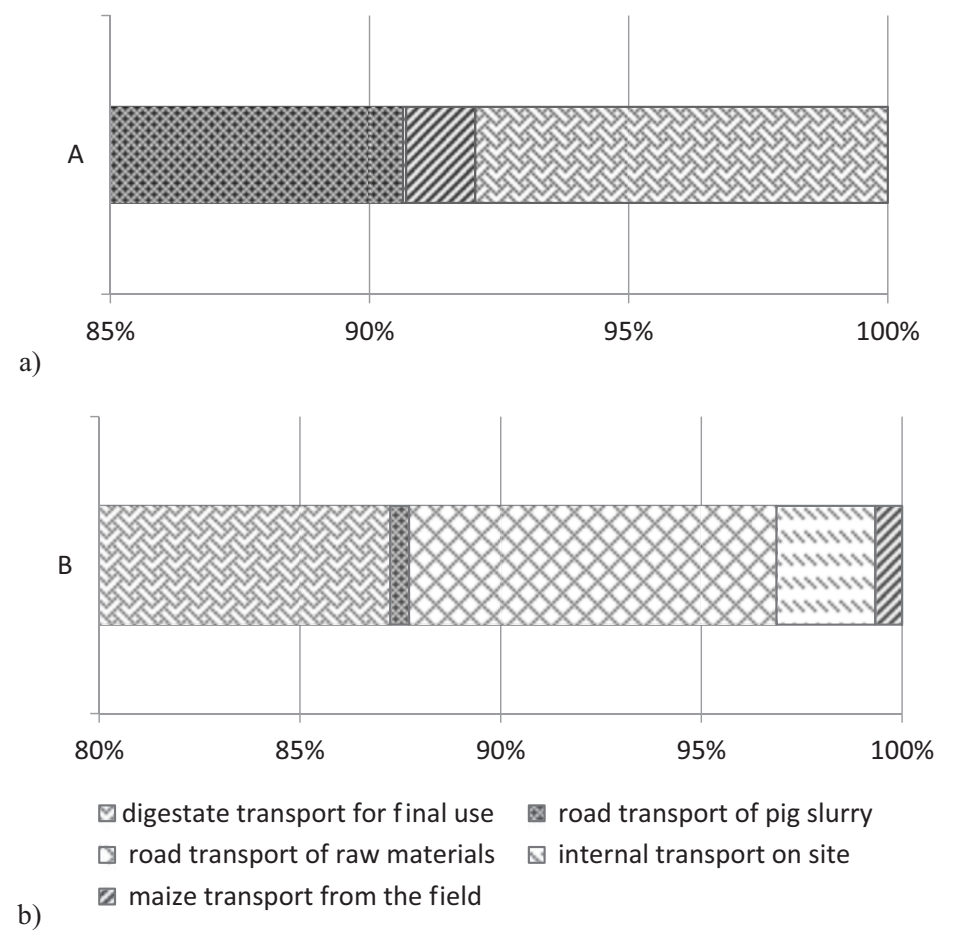

Fig. 2 The share of different types of transport in feedstock delivery process: (a) biogas plant A, (b) biogas plant $\mathrm{B}$

\section{Conclusions}

The production of renewable energy from biogas is an unquestionably effective way to replace energy from conventional sources and reduce negative environmental impact and climate change. Biogas plants can also provide a solution to the problem of managing many agricultural and agri-food industry waste. However, taking into account many previous studies and this work, we can conclude that transport is the main contributor of the cumulative environmental impact of operating an agricultural biogas plant. Liquid raw materials with a low biogas yield should be transported by pipelines, and biogas plants using this type of raw materials should be located in the vicinity of feedstock sources. This is also confirmed by Cherubini et al. who claimed that keeping animals close to biogas plant provide the reduction of the environmental impact [19].

In the case of the ferment, the distance over which it is to be extracted should be limited or other solutions should be used to limit the quantity of the ferment that is needed to be used, e.g. by drying. The environmental impact of drying processes and the possible pelletization of the resulting biomass should be studied. 
Undoubtedly, biomass waste is a key source of renewable energy (not only a biogas), but we have to be aware of the possible environmental impact.

\section{References}

1. Battini, F., Agostini, A., Boulamanti, A. K., Giuntoli, J., \& Amaducci, S. (2014). Mitigating the environmental impacts of milk production via anaerobic digestion of manure: Case study of a dairy farm in the Po Valley. Science of the Total Environment, 481, 196-208. https://doi. org/10.1016/j.scitotenv.2014.02.038

2. Neshat, S. A., Mohammadi, M., Najafpour, G. D., \& Pooya, L. (2017). Anaerobic co-digestion of animal manures and lignocellulosic residues as a potent approach for sustainable biogas production. Renewable and Sustainable Energy Reviews, 79, 308-322.

3. Burg, V., Bowman, G., Haubensak, M., Baier, U., \& Thees, O. (2018). Valorization of an untapped resource: Energy and greenhouse gas emissions benefits of converting manure to biogas through anaerobic digestion. Resources, Conservation and Recycling, 136, 53-62. https://doi.org/10.1016/j.resconrec.2018.04.004

4. Möller, K. (2015). Effects of anaerobic digestion on soil carbon and nitrogen turnover, $\mathrm{N}$ emissions, and soil biological activity. A review. Agronomy for Sustainable Development, 35, 1021. https://doi.org/10.1007/s13593-015-0284-3

5. Timonen, K., Sinkko, T., Luostarinen, S., Tampio, E., \& Joensuu, K. (2019). LCA of anaerobic digestion: Emission allocation for energy and digestate. Journal of Cleaner Production, 235, 1567-1579. https://doi.org/10.1016/j.jclepro.2019.06.085

6. Al Seadi, T. (2002). Quality management of AD residues from biogas production. In IEA bioenergy, task 24 - Energy from biological conversion of organic waste. University of Southern Denmark. http://213.229.136.11/bases/ainia_probiogas.nsf/0/70996A6A88900B70C12575 3F005B70AD/\$FILE/IEA\%20BUENAS\%20PR\%C3\%81CTICAS\%20DA.pdf. Accessed online on 4 Jun 2021

7. Alburquerque, J. A., de la Fuente, C., \& Bernal, M. P. (2012). Chemical properties of anaerobic digestates affecting $\mathrm{C}$ and $\mathrm{N}$ dynamics in amended soils, agriculture. Ecosystems \& Environment, 160, 15-22. https://doi.org/10.1016/j.agee.2011.03.007

8. Morero, B., Groppelli, E., \& Campanella, E. A. (2015). Life cycle assessment of biomethane use in Argentina. Bioresource Technology, 182, 208-216. https://doi.org/10.1016/j. biortech.2015.01.077

9. Boulamanti, A. K., Maglio, S. D., Giuntoli, J., \& Agostini, A. (2013). Influence of different practices on biogas sustainability. Biomass and Bioenergy, 53, 149-161. https://doi. org/10.1016/j.biombioe.2013.02.020

10. Agostini, A., Battini, F., Giuntoli, J., Tabaglio, V., Padella, M., Baxter, D., Marelli, L., \& Amaducci, S. (2015). Environmentally sustainable biogas? The key role of manure codigestion with energy crops. Energies, 8, 5234-5265.

11. Russo, V., \& von Blottnitz, H. (2017). Potentialities of biogas installation in South African meat value chain for environmental impacts reduction. Journal of Cleaner Production, 153, 465-473. https://doi.org/10.1016/j.jclepro.2016.11.133

12. Hamelin, L., Naroznov, I., \& Wenzel, H. (2014). Environmental consequences of different carbon alternatives for increased manure-based biogas. Applied Energy, 114, 774-782. https:// doi.org/10.1016/j.apenergy.2013.09.033

13. Fantin, V., Giuliano, A., Manfredi, M., Ottaviano, G., Stefanova, M., \& Masoni, P. (2015). Environmental assessment of electricity generation from an Italian anaerobic digestion plant. Biomass and Bioenergy, 83, 422-435. https://doi.org/10.1016/j.biombioe.2015.10.015 
14. Poeschl, M., Ward, S., \& Owende, P. (2010). Prospects for expanded utilization of biogas in Germany. Renewable and Sustainable Energy Reviews, 14(7), 1782-1797. https://doi. org/10.1016/j.rser.2010.04.010

15. ISO 14040:2006 Environmental management - Life cycle assessment - Principles and framework.

16. ISO 14044:2006 Environmental management - Life cycle assessment - Requirements and guidelines.

17. European Commission -Joint Research Centre -Institute for Environment and Sustainability. (2010). International Reference Life Cycle Data System (ILCD) Handbook -general guide for life cycle assessment -detailed guidance. First edition March 2010. EUR 24708 EN. Luxembourg. Publications Office of the European Union. Accessed 15 Jan 2020.

18. Hartmann, J. K. (2006). Life-cycle-assessment of industrial scale biogas plants. Department for Agricultural Science, Georg-August-Universitat Gottingen. Accessed 15 Jan 2020.

19. Cherubini, E., Zanghelini, G. M., Alvarenga, R. A. F., Franco, D., \& Soares, S. R. (2015). Life cycle assessment of swine production in Brazil: A comparison of four manure management systems. Journal of Cleaner Production, 87, 68-77. https://doi.org/10.1016/j.jclepro.2014.10.035

Open Access This chapter is licensed under the terms of the Creative Commons Attribution 4.0 International License (http://creativecommons.org/licenses/by/4.0/), which permits use, sharing, adaptation, distribution and reproduction in any medium or format, as long as you give appropriate credit to the original author(s) and the source, provide a link to the Creative Commons license and indicate if changes were made.

The images or other third party material in this chapter are included in the chapter's Creative Commons license, unless indicated otherwise in a credit line to the material. If material is not included in the chapter's Creative Commons license and your intended use is not permitted by statutory regulation or exceeds the permitted use, you will need to obtain permission directly from the copyright holder. 